\title{
MORPHOLOGICAL CHANGES IN THE VAGINAL EPITHELIUM DURING THE OESTROUS CYCLE OF Calomys callosus (Rodentia, Cricetidae)
}

\author{
JEAN FÁBIO TORRES RODRIGUES and ELOISA AMÁLIA VIEIRA FERRO \\ Department of Morfhology, Federal University of Uberlândia, Uberlândia, Minas Gerais, Brazil \\ Address correspondence to: Eloisa Amália Vieira Ferro, Departamento de Morfologia, \\ Universidade Federal de Uberlândia, Av. Pará,1720, Campus Umuarama, \\ CEP 38400-902, Uberlândia, MG, Brazil \\ Received October 10, 1996 - Accepted May 05, 1998 - Distributed August 28, 1998
}

(With 22 figures)

\begin{abstract}
This study describes changes in the pattern of microridges, keratinization, desquamation, secretion, leukocyte infiltration as well as the increasing number of mitotic cells in the vaginal epithelium of Calomys callosus during the oestrous cycle. In proestrus, the epithelium is squamous and stratified with a fine layer of keratin and it is overlain by secretory prismatic cells. In oestrous, the epithelium is squamous, stratified and keratinized. In metoestrus, the epithelium is squamous and stratified with loss of the keratin layer. A leukocyte infiltration, extending from the base to the surface of the epithelial layer is also present. At the end of this phase, the surface cells start to become PAS-positive. In dioestrus, the epithelium is stratified. The superficial cells are prismatic, exhibiting the structural and ultrastructural characteristics of glycoprotein secreting cells supported by a layer of squamous cells. At the end of this phase, kerato-hyaline granules appear in the granular layer of the epithelium, indicating the beginning of the keratinization process, present in the next proestrus.
\end{abstract}

Key words: oestrous cycle, vaginal epithelium, Calomys callosus, keratinization, secretion, leukocyte infiltration.

\section{RESUMO}

\section{Alterações morfológicas do epitélio vaginal de Calomys callosus (Rodentia, Cricetidae) durante o ciclo estral}

Neste estudo são descritas mudanças que ocorrem nos padrões de microrrugas, queratinização, descamação, secreção, infiltração leucocitária e aumento no número de células em mitose no epitélio vaginal de Calomys callosus durante o ciclo estral. No proestro, o epitélio é estratificado pavimentoso, com uma fina camada de queratina e, sobre esta camada, há células prismáticas secretoras. No estro, o epitélio é estratificado pavimentoso e queratinizado. No metaestro, o epitélio é estratificado pavimentoso com poucas camadas de queratina. Infiltrados leucocitários estão presentes desde a base até as camadas superficiais do epitélio. No final desta fase as células da superficie começam a se tornar PAS-positivas. No diestro, o epitélio é estratificado. As células superficiais são prismáticas, exibindo características estruturais e ultra-estruturais de células secretoras de glicoproteínas, as quais estão apoiadas sobre camada de células pavimentosas. No final desta fase, aparecem grânulos de queratohialina na camada granulosa do epitélio, indicando o começo do processo de queratinização, presente no proestro.

Palavras-chave: ciclo estral, epitélio vaginal, Calomys callosus, queratinização, secreção, infiltração leucocitária. 


\section{INTRODUCTION}

Calomys callosus is a species of South American animal recently introduced in laboratory research. It is a cricetidae rodent widely found in Brazilian territory and easily adapted to laboratory conditions (Mello, 1981; Peter et al., 1967; Justines $\&$ Johnson, 1970). From a medical point of view $C$. callosus is the reservoir for Trypanosoma cruzi, the etiologic agent of Chagas's disease (Ribeiro, 1973), and for the agent of Argentine hemorrhagic fever (Justines \& Johnson, 1969). From the reproductive point of view, $C$. callosus is a polyestrus rodent and has a postpartum oestrus. The species is characterized by an oestrous cycle of 6.6 days duration, puberty occurs frequently with 40,1 days $( \pm 7,6)$ in female and 19,6 days ( \pm 6.6) in male (Mello, 1978). The adult animal has $12 \mathrm{~cm}$ long, weighs $30 \pm 8 \mathrm{~g}$ and the number of youngs born is $5 \pm 3$. Although several studies have been published about this species, morphological changes in the vaginal epithelium during the oestrous cycle are not known. Cyclical changes in the vaginal epithelium during oestrous cycle have been described in many animal species. In general, these changes are characterized by keratinization, acquisition of secretory activity by the epithelial surface, variation in the number of mitotic figures in the germinative stratum with consequent increase in thickness of the epithelium, leukocyte infiltration through the epithelial cells to the lumen of the organ, and an increase in the population of Langerhans cells among the keratinocytes.

The purpose of this study was to examine the morphological changes in vaginal epithelium of $C$. callosus during the oestrous cycle with light microscopy (LM), transmission electron microscopy (TEM) and scanning electron microscopy (SEM).

\section{MATERIALS AND METHODS}

Eighteen, twelve-week-old, female $C$. callosus were obtained from the Tropical Medicine Institute of São Paulo. The animals were housed at $26+2^{\circ} \mathrm{C}$ under a 12 -h light, 12 -h dark light period and received water, granulated ration (Purina), sunflower seeds and corn ad libitum.

Every morning vaginal smears were taken, stained using Shorr's technique (1945) and analyzed under the LM to define the phase of the cycle. Three females were sacrificed to characterize each cycle phase. The animals were anaesthetized by ether inhalation. After laparotomy, the dissection was initiated in the median region of the vagina, dividing it into 3 fragments. The first fragment was processed for LM, the second fragment for TEM and the last for SEM.

The first fragments were fixed in a solution of $95 \%$ ethanol, formalin, glacial acetic acid and distilled water $(3: 1: 1: 5 \mathrm{v} / \mathrm{v})$ (Finn \& McLaren, 1967) for 18 hours. The fragments were then routinely processed for Glycol methacrylate embedding (Historesin, LKB). Sections of $2 \mu \mathrm{m}$ thickness were stained with $0,25 \%$ toluidine blue in distilled water at $40^{\circ} \mathrm{C}$. Some sections were treated using the Periodic-acid-Schiff (PAS) reaction according to McManus (1948).

Second fragments were fixed for about 3 hours in a mixture of equal parts of $2 \%$ glutaraldehyde and $2 \%$ paraformaldehyde in $0.1 \mathrm{M}$ phosphate buffer at $\mathrm{pH}$ 7.4.

They were then washed in $0.1 \mathrm{M}$ phosphate buffer at $\mathrm{pH} 7.4$, post-fixed in $1 \%$ osmium tetroxide in $0.1 \mathrm{M}$ phosphate buffer at $\mathrm{pH} 7.4$ during 1 $\mathrm{h}$, embedded in Epon and analyzed in a Zeiss EM109 Electron Microscope. The third fragments were fixed broadly similarly to the second fragments and were dehydrated in an ascending series of ethanol, dried with $\mathrm{CO}_{2}$ in a critical-point dryer (Balzers), mounted on metal stubs with silver paint, coated with $9 \mathrm{~nm}$ gold in a sputter coated and analyzed in a Zeiss DSM 950 Scanning Electron Microscope.

\section{RESULTS}

\section{Proestrus}

In this phase, the epithelium was squamous, stratified and keratinized, exhibiting about 20 layers of cells. PAS-positive, prismatic cells (Fig. 1) were observed on the keratinized layer.

In the basal third of the epithelium, the cells were cylindrical and mitotic figures were seldom observed. In this layer, the nucleus were predominantly euchromatic with evident nucleolus. The junction between the cells and the basal lamina was characterized by hemidesmosomes, and among adjoining epithelial cells, by typical desmosomes. In the cytoplasm, there were large quantities of mitochondria with lamellar cristae, cisternae of granular endoplasmic reticulum and numerous, free polyribosomes. Filaments of 
approximately $10 \mathrm{~nm}$ diameter, either isolated or in bundles, and lipid droplets were also observed.

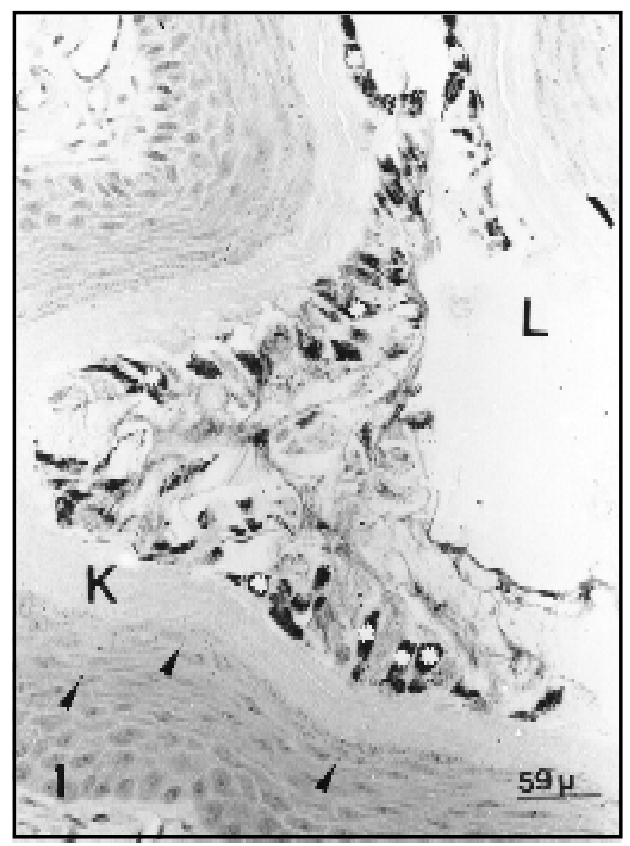

Fig. 1 - Vaginal epithelium of Calomys callosus in proestrus stained with PAS and observed by LM. In this phase the epithelium is thick, presenting kerato hyaline granules (arrowheads) and a keratinized layer (K). In the vaginal lumen (L) many PAS-positive cells (asterisk) are supported on the keratinized layer. 170X.

In the middle third, most cells were globous or squamous; the other characteristics described for the basal layer were present, although the number of the desmosomes was greater (Fig. 2).

In the apical portion, two distinct cellular populations were observed: an internal layer contained squamous cells, and an external layer exhibited prismatic secretory cells which secreted PAS-positive material. In the squamous cell layer, two further regions were distinguished: an inferior region, in contact with the cells of the middle third, and a superior region, in contact with the secretory cells layer. The inferior region was composed by cytoplasms of the cells which were filled with $10 \mathrm{~nm}$ of diameter filaments and kerato-hyaline granules. A reduction in the number of mitochondria and cisternae of granular endoplasmic reticulum compared to the basal and middle layers was observed, although the large number of free polyribosomes still persisted. The nucleus presented the same characteristics as seen in the previously described portions. The superior region exhibited cells containing cytoplasm filled with an amorphous, homogeneous and electrondense substance. Nucleus and other organelles were not observed. A linear accumulation of electron-dense material near the plasmatic membrane was observed (Fig. 3).

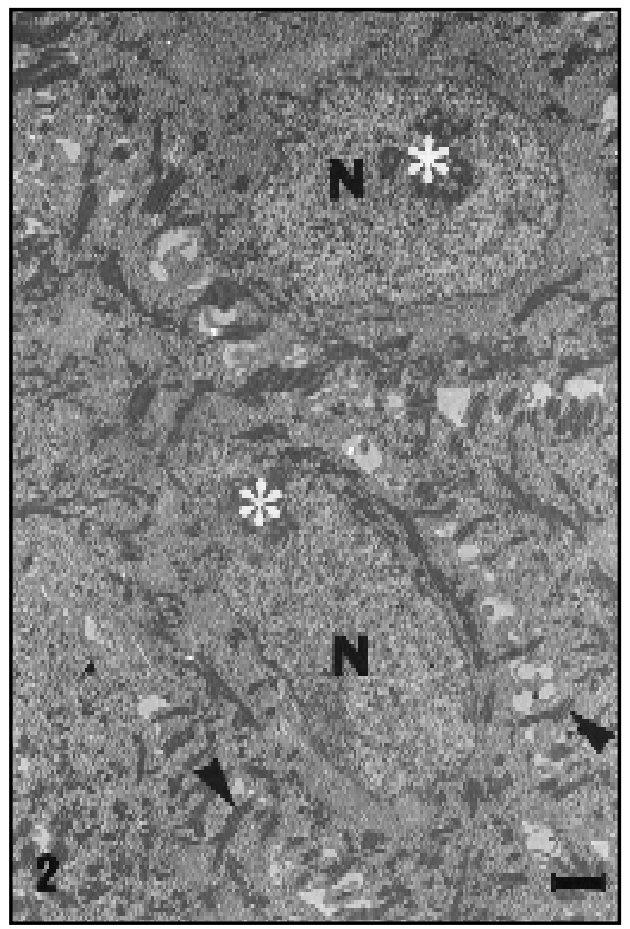

Fig. 2 - Electronmicrograph of vaginal epithelium of Calomys callosus during proestrus. Middle region of the vaginal epithelium. Nucleus (N) with prominent nucleolus (asterisk). In the cytoplasm, numerous keratin filaments (arrowheads) grouped in bundles or adhering to desmosomes. $6000 \mathrm{X}$. Bar $-1 \mu \mathrm{m}$.

The secretory cells presented predominantly heterochromatic nucleus. Their c ytoplasm revealed organelles in different degrees of degeneration. There were numerous secretory granules of variable electron density in the cytoplasm (Fig. 4). Surface of epithelium exhibited high cells covered with microridges (Figs. 5 and 6). The vaginal lumen was characterized by the presence of many PAS-positive, epithelial cells undergoing desquamation.

\section{Oestrus}

In this phase, the epithelium was stratified, squamous and keratinizated and constituted by approximately 35 to 40 layers of cells (Fig. 7). 
In the basal portion, the cells were similar to those in the same region in the proestrus phase. Mitotic figures were common. In the cytoplasm, well developed granular endoplasmic reticulum, free polyribosomes, $10 \mathrm{~nm}$ diameter filaments and mitochondria presenting either lamellar or tubular cristae (Fig. 8) were observed.

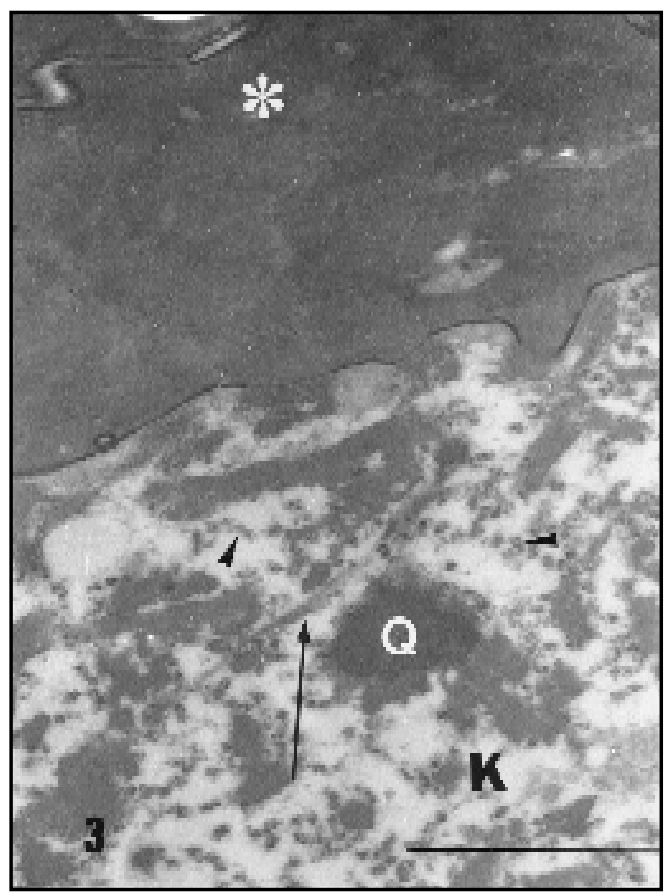

Fig. 3 - Vaginal epithelium of Calomys callosus in proestrus observed by TEM. Interface between keratinized cells (asterisk) and cells in the process of keratinization (K). In this cell there are numerous free polyribosomes (arrowheads), kerato-hyaline granules $(\mathrm{Q})$ and bundles of intermediate filaments (arrow). 29000X. Bar $-1 \mu \mathrm{m}$.

In the middle portion, the cells have already acquired a squamous form, presenting nuclei with loose chromatin. In the cytoplasm, few organelles were observed with the exception of free polyribosomes. There was an increase in the quantity of kerato-hyaline granules and $10 \mathrm{~nm}$ filament bundles. At some points in the layer of contact with the keratinized portion, these filament bundles adhered to the internal face of the desmosomes, which confered the coupling between the cells of this layer and the keratinized layer (Fig. 9).

In the apical portion, the cells were keratinized and their cytoplasms were completely filled with an amorphous, homogeneous, and electrondense substance; residues of nuclei could be observed at some points. The adherence of the adjoining keratinized cells was effected by desmosomes. At these sites, an electron-dense material was deposited on the internal face of the plasma membrane (Fig. 9). The surface epithelium showed flattened cells in process of sloughing (Fig. 10). At low magnification some surface cells possessed connected microridges (Fig. 11).

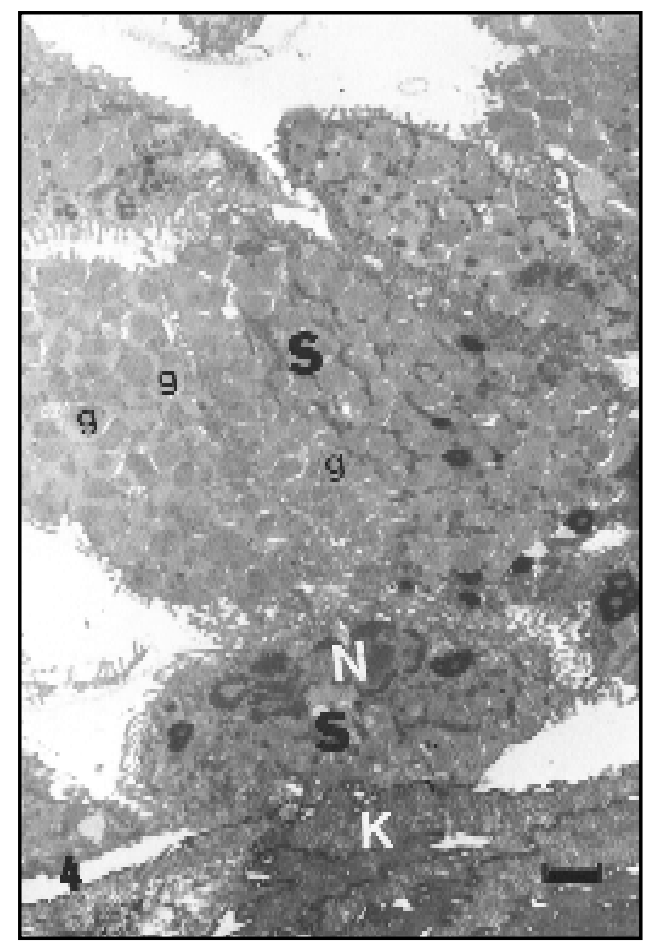

Fig. 4 - Vaginal epithelium of Calomys callosus in proestrus observed by TEM. Interface between keratinized cells (K) and secretory cells (S). The plasma membrane of the secretory cells exhibits numerous microvilli. In the cytoplasm there are secretory granules $(\mathrm{g})$; the nucleus $(\mathrm{N})$ presents an irregular profile and condensed chromatin. 6000X. Bar $-1 \mu \mathrm{m}$.

\section{Metoestrus 1}

In this phase, the epithelium was squamous, stratified and composed of 9 to 10 cell layers. Infiltrated leukocytes were observed among the epithelial cells (Fig. 12). In the vaginal lumen, keratinized, desquamated, epithelial cells were present. The basal and middle portions were similar to those described in the previous phase. The apical portion presented squamous cells (Fig. 13). In the cytoplasm, mitochondria with lamellar cristae, cisternae of granular endoplasmic reticulum, free polyribosomes and $10 \mathrm{~nm}$ diameter filament were observed. 

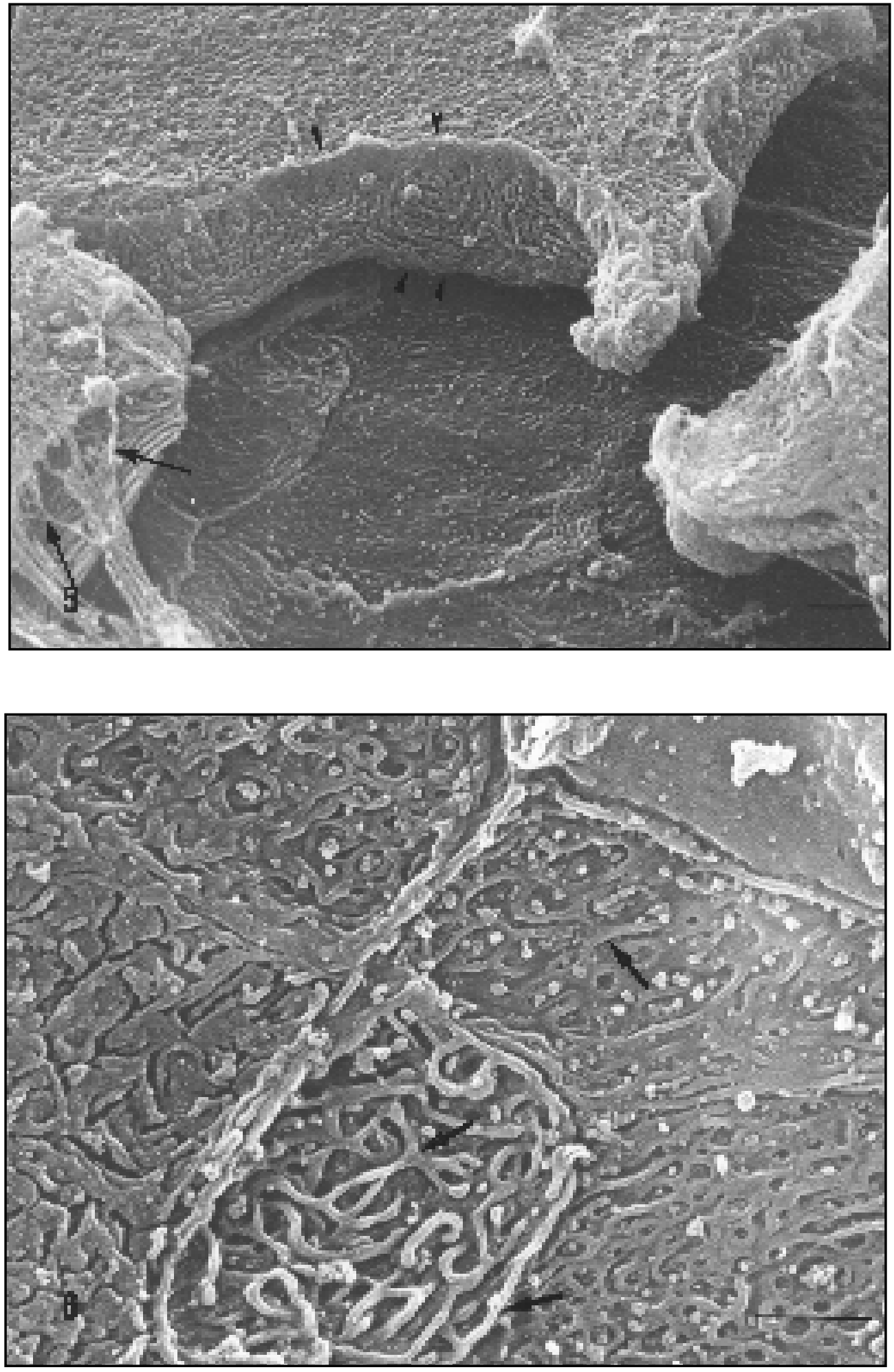

Figs. 5 and 6 - Scanning electronmicrographs from the vaginal epithelium of Calomys callosus in proestrus. Fig. 5 - Luminal surface of vaginal epithelium with mucus (arrow) and microridges (arrowheads). 10000X. Bar $1 \mu \mathrm{m}$. Fig. 6 - Higher magnification the surface of cells covered with microridges (arrow). 17000X. Bar $-1 \mu \mathrm{m}$. 


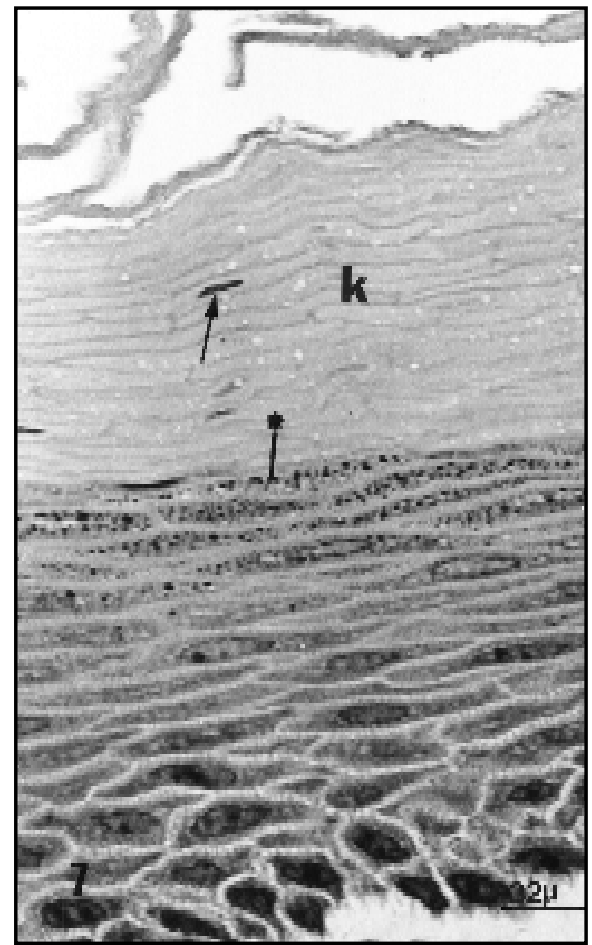

Fig. 7 - Vaginal epithelium during oestrous obseved by LM. The epithelium is stratified, squamous and keratinized (K). Below this layer there are many kerato-hyaline granules (asterisk). $310 \mathrm{X}$.

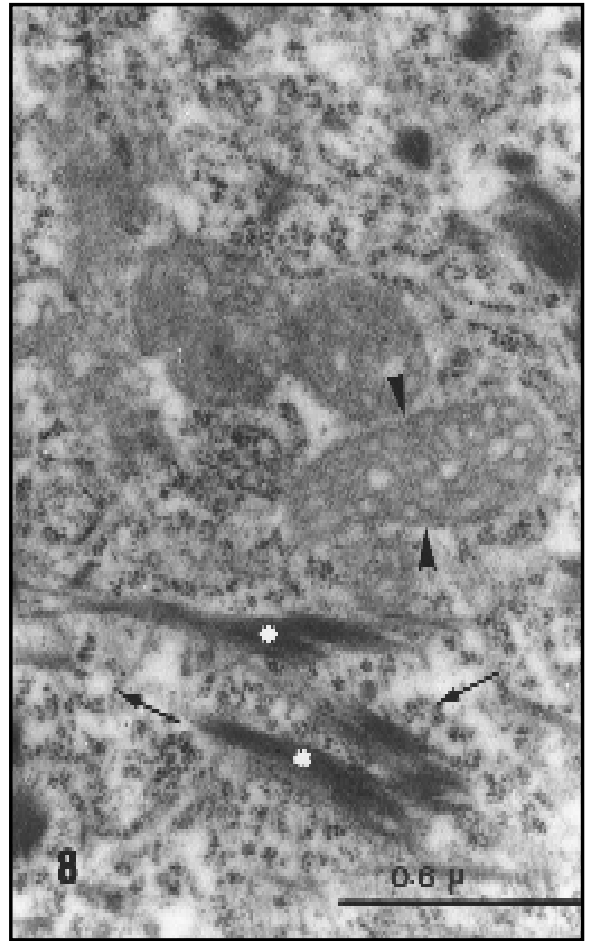

Fig. 8 - Electronmicrograph of vaginal epithelium of Calomys callosus during oestorus. Middle region of the vaginal epithelium where mitochondria (arrowheads) with tubular cristae, bundles of intermediate filaments (asterisk), and free polyribosomes (arrow) are seen. 48500X.

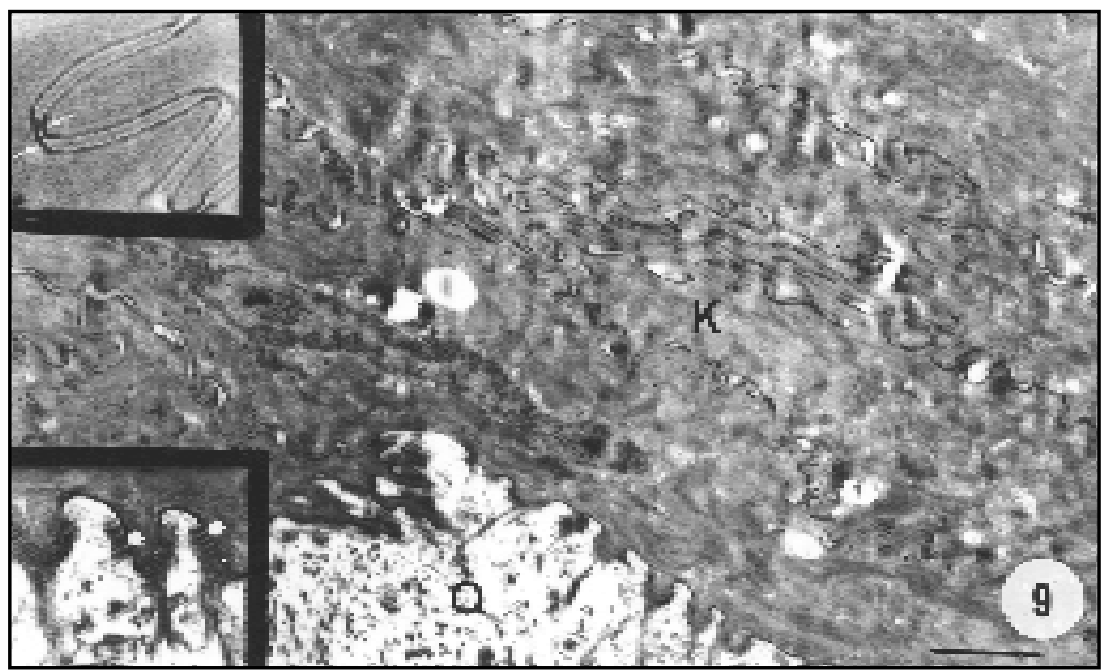

Fig 9 - Electronmicrographs of vaginal epithelium of Calomys callosus during oestrous. Interf ace between keratinized (K) and non-keratinized layer $(\mathrm{Q})$. The upper left insert demonstrates desmosomes seen in the keratinized layer. The two membranes forming each desmosome are in close juxtaposition and there are deposits of electron dense material on the in cytoplasmic faces (arrows). The lower left insert shows the transition zone between the keratinized and non-keratinized layer. The non-keratinized layer is marked by the presence of numerous desmosomes (asterisk) into which intermediate filaments are inserted. 14000X. Upper left insert $-40000 X$. Lower left insert $-20000 X$. Bar $-1 \mu \mathrm{m}$. 

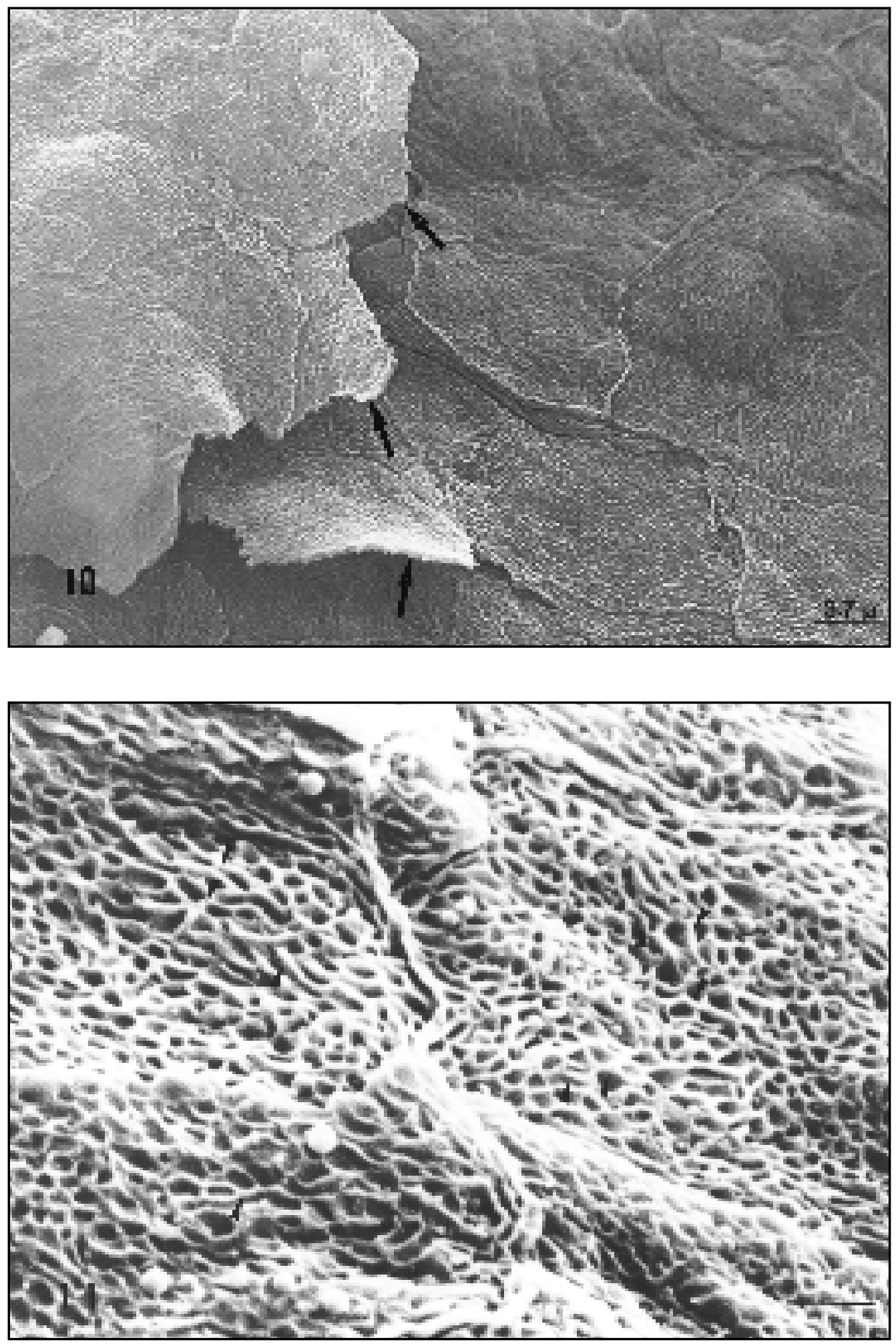

Figs. 10 and 11 - Scanning electronmicrographs of the vaginal epithelium of Calomys callosus in oestrus. Fig. $10-$ Surface view of a fully keratinizated epithelium showing cells in the process of sloughing (arrow). 2700X. Fig. 11 - At higher magnification the surface of these cells have complex microridges (arrow). 13000X. Bar $-1 \mu \mathrm{m}$. 


\section{Metoestrus 2}

The epithelium was characterized by the presence of approximately 9 to 10 layers of cells and occasional mitotic figures. In this phase, the leukocytes accumulated in the apical layers of the epithelium (Fig. 14) and vaginal lumen characteristically presented desquamation of epithelial cells, together with a few leukocytes. The basal cells and those of the middle portion presented characteristics similar to those seen in the previous phase. The apical portion differed from last phase in that it was PAS-positive (Fig. 14) and presented glycogen deposits (Fig. 15).

The surface epithelium similary to metoestrus 1 and metoestrus 2, showed flattened cells with microridges in process of sloughing, very closely resembling that at oestrus (Fig. 16).

\section{Dioestrus 1}

In this phase, the epithelium were approximately 5 cell layers thick with an accentuated infiltration of leukocytes among the keratinocytes. In the basal third, the cells were prismatic and mitotic figures were rare. In the apical third, tall cubic and prismatic cells were present (Fig. 17). Ultrastructurally the cytoplasm of the cells presented mitochondria, cisternae of granular endoplasmic reticulum, Golgi complexes and secretion granules (Fig.18). Surface cells showed microridges. The number of the microridges was variable, numerous in some cells and few in others (Fig. 19).

\section{Dioestrus 2}

The epithelium was characterized by the presence of 15 to 20 layers of cells. Some mitotic figures were observed in the basal third of the epithelium. In the middle third, the cells were squamous and became progressively filled with kerato-hyaline granules towards the epithelial surface.

The superficial cells were prismatic or globous and their content was PAS-positive (Fig. 20). In these cells, the nuclei were located at the basal pole, being visibly heterochromatic and apparently in the process of degeneration. The cytoplasm presented secretion granules and dilated cisternae of granular endoplasmatic reticulum. On the surface, expansions were seen, suggesting figures of granule extrusion to the lumen (Figs. 21 and 22).

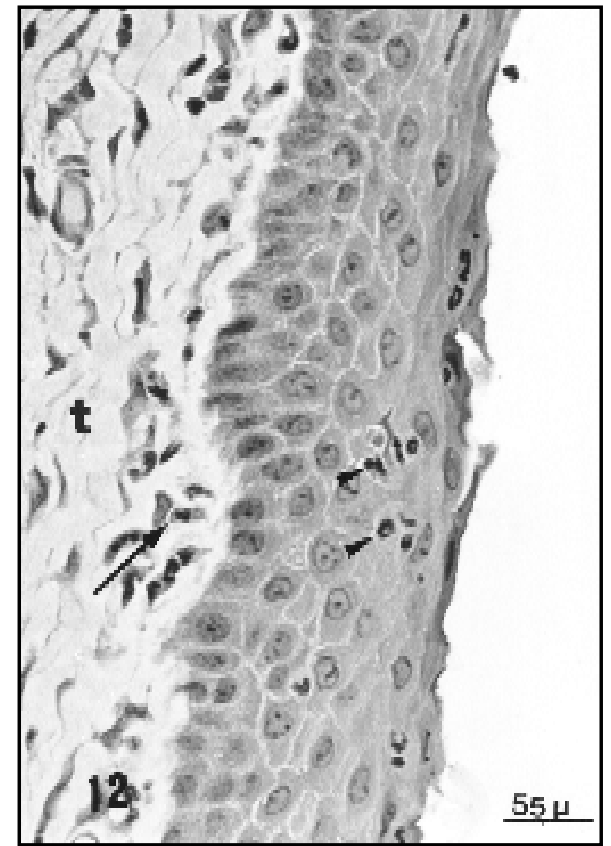

Fig. 12 - Vaginal epithelium of Calomys callosus in metoestrus 1 stained with PAS and observed by LM. The epithelium is stratified and squamous. Among the epithelial cells in the middle and upper epithelial layers, numerous infiltrated leukocytes are found (arrowheads). Leukocyte (arrow) infiltration is seen in the connective tissue (t). 180X.

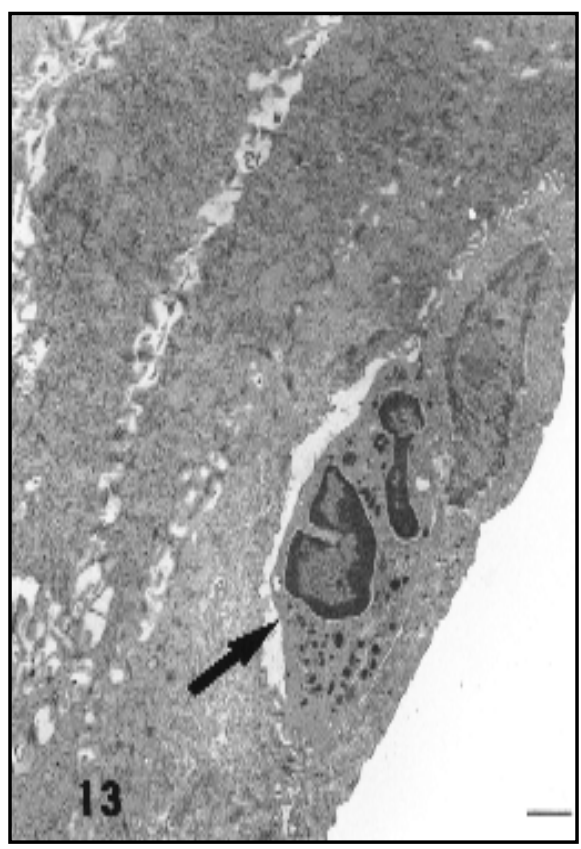

Fig. 13 - Electronmicrographs of vaginal epithelium of Calomys callosus during metoestrus 1 . In this electronmicrograph a leukocyte is located (arrow) among the epithelial cells. 5000X. Bar $-1 \mu \mathrm{m}$. 


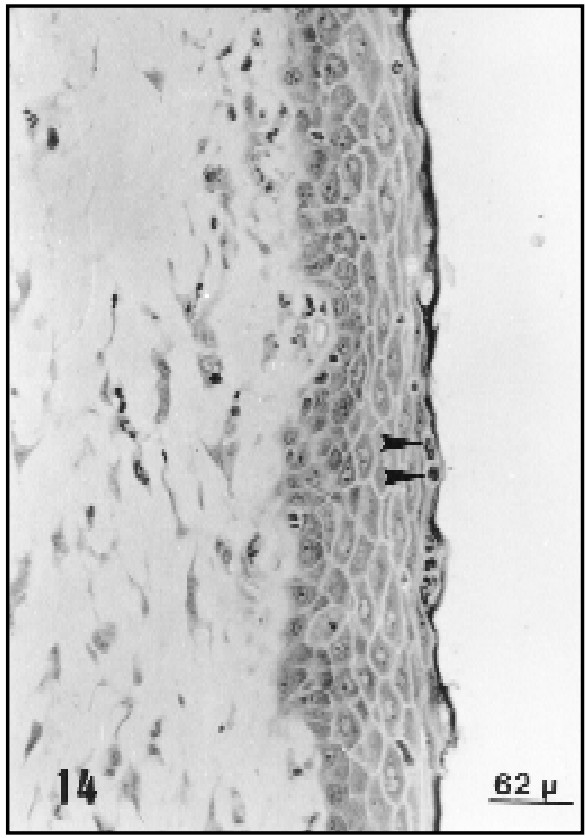

Fig 14 - Vaginal epithelium of Calomys callosus in metoestrus 2 stained with PAS and observed by LM. In this phase, leukocytes predominate in the upper layer of the epithelium (arrowheads) which is PAS-positive. 160X.

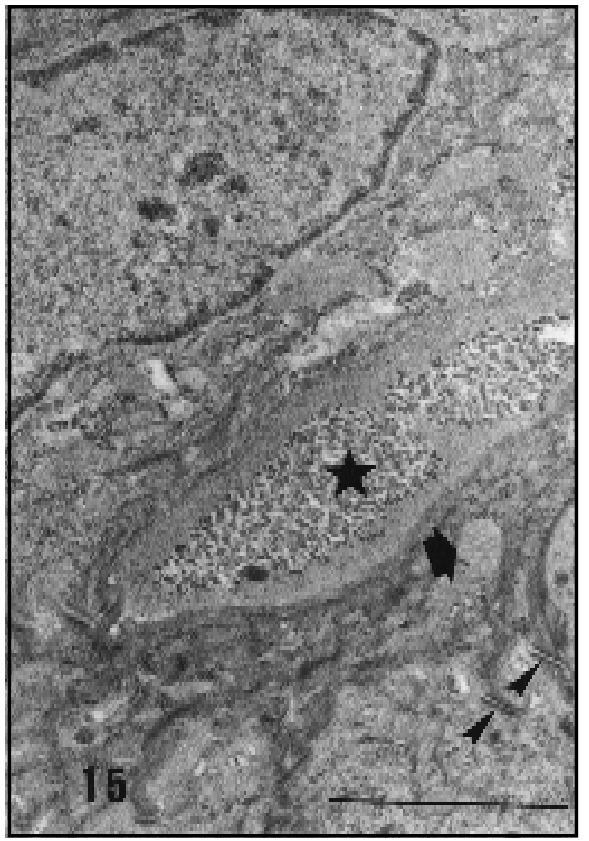

Fig. 15 - Electronmicrograph of the upper region of the epithelium seen in the previous figure. Observe the nucleus, mitochondria (arrow), desmosomes (arrowheads) and re gion of glycogen accumulation (star). 26000X. Bar $-1 \mu \mathrm{m}$.

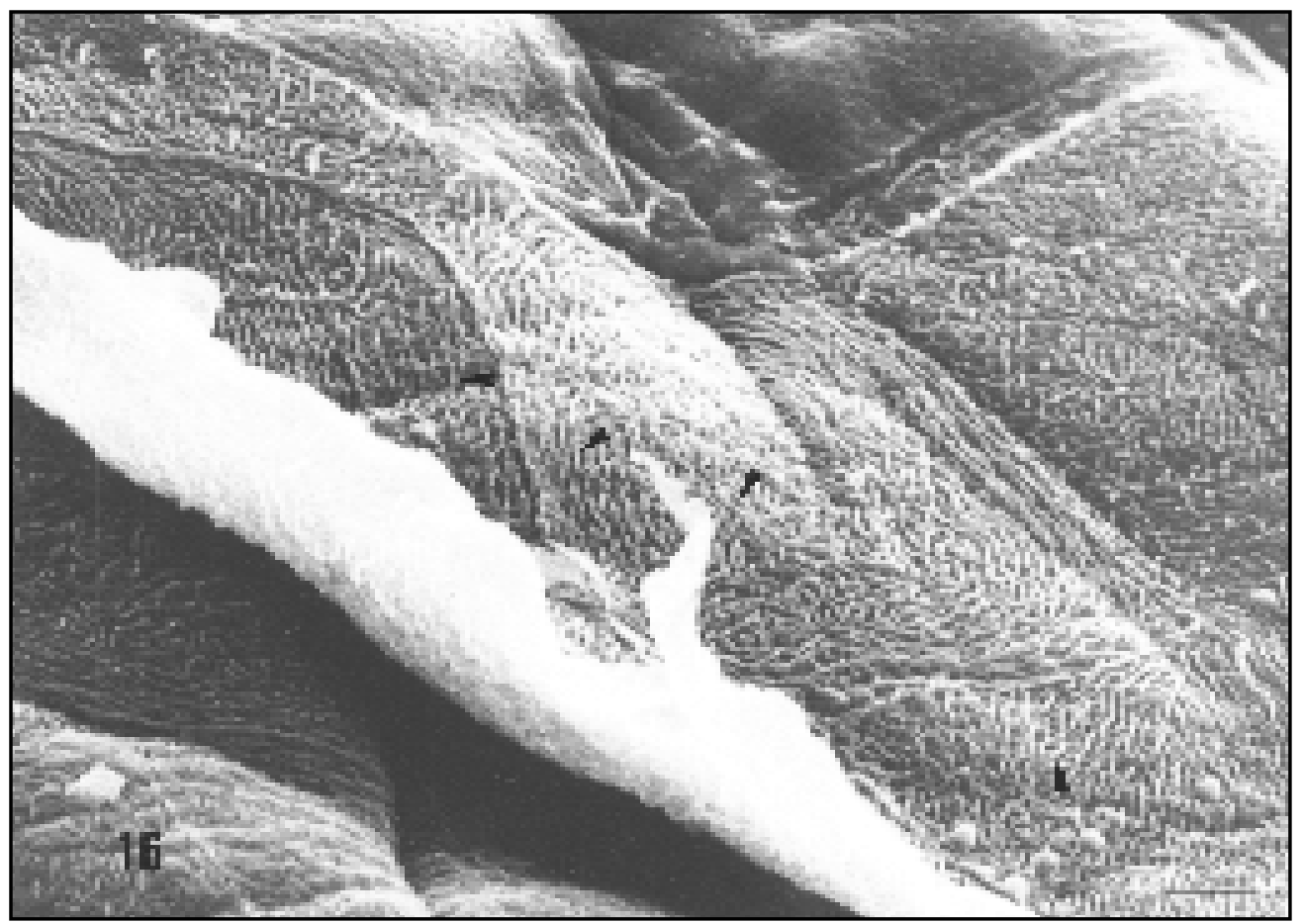

Fig. 16 - Scanning electron micrograph of the vaginal epithelium of Calomys callosus in metoestrus. The cells are in process of sloughing and show microridges at their surfaces (arrowhead). 9000X. Bar $-1 \mu \mathrm{m}$. 


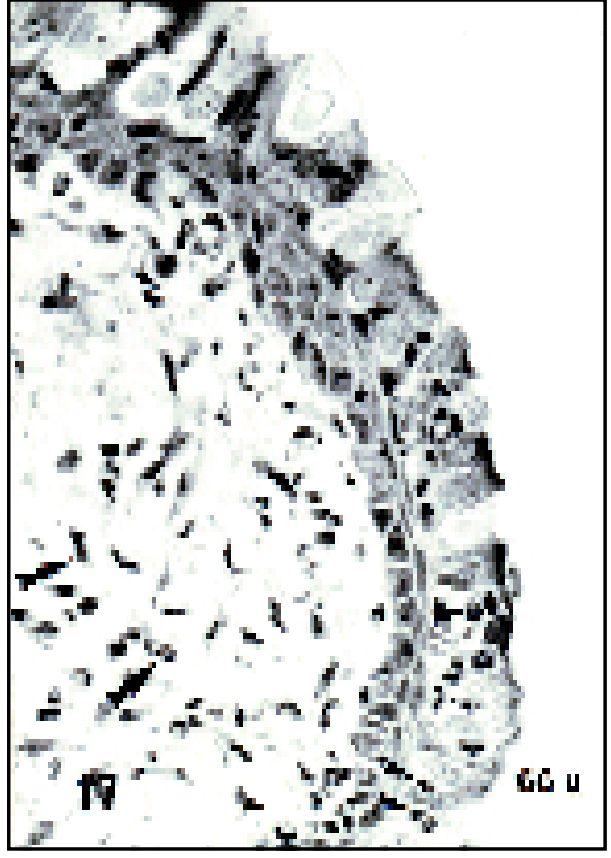

Fig 17 - Vaginal epithelium of Calomys callosus in dioestrus 1 stained with PAS and observed by LM. The epithelium comprises few cell layers and the superficial layer cells are cubic. In the connective tissue, leukocytes (arrow) also insinuate (arrowhead) among the epithelial cells. 150X.

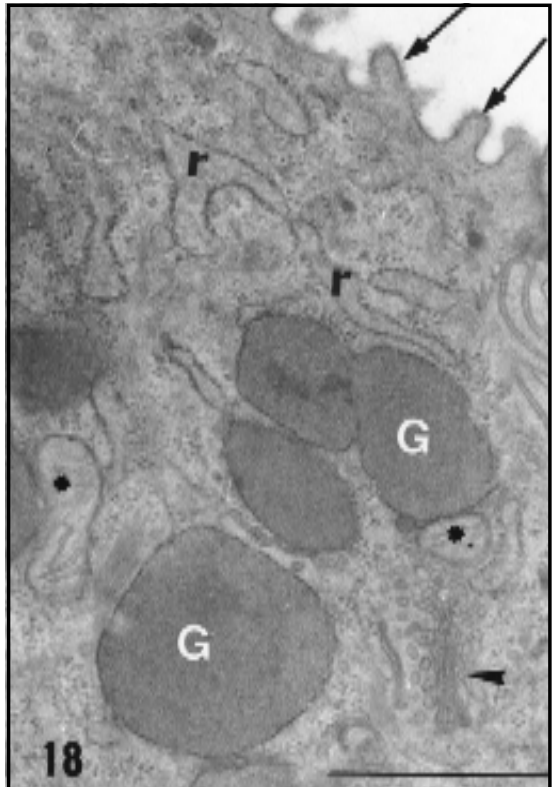

Fig. 18 - Elect ronmicrograph of vaginal epithelium of Calomys collosus during dioestrous 1 . Cubic cells seen in the previous figure. The presence of microvilli on the surface of these cells is common (arrow). Secretory granules (G), Golgi complex (arrowhead), mitochondria (asterisk) and granular endoplasmic reticule (r) are seen in the cytoplasm. 28000X. Bar $-1 \mu \mathrm{m}$.

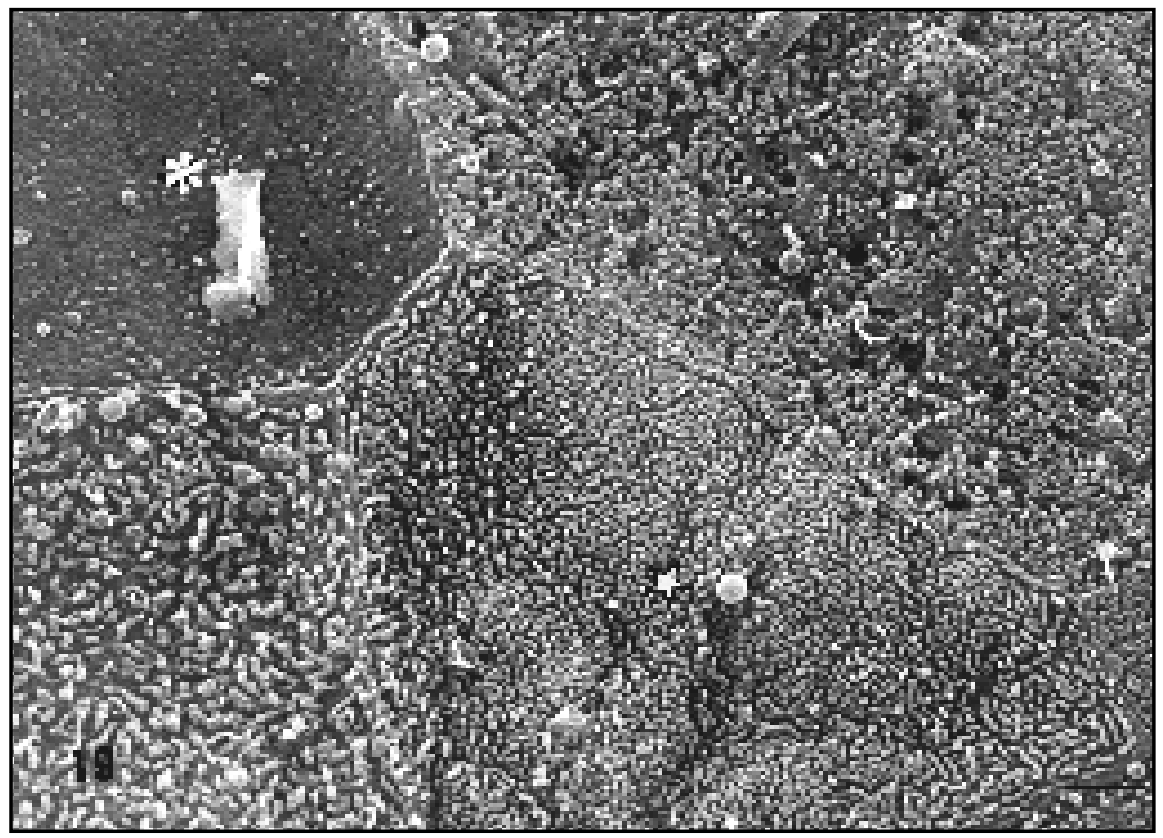

Fig 19 - Scanning electron micrograph of the luminal surface of the vaginal epithelium in dioestrus 1. Cell surface with few microridges (asterisk) or with many microridges (star). 12000X. Bar $-1 \mu \mathrm{m}$. 


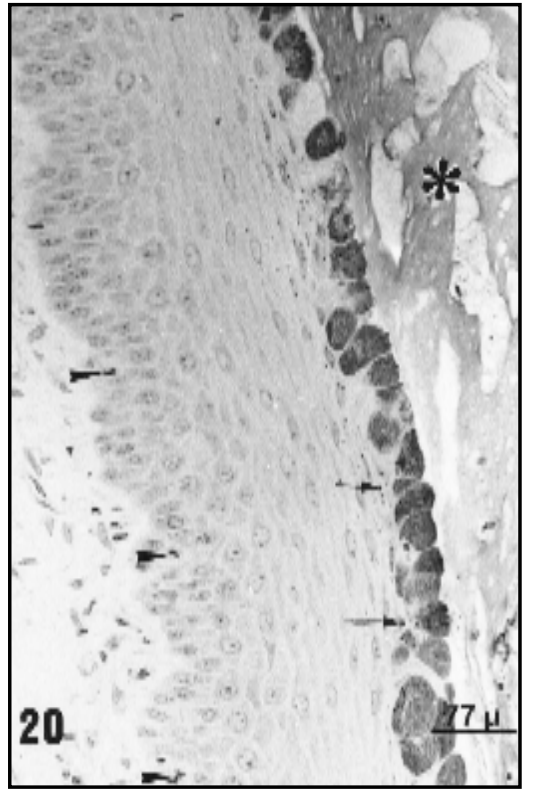

Fig. 20 - Vaginal epithelium of Calomys callosus in dioestrous 2 stained with PAS an observed by LM. A thicker epithelium is observed; mitotic figures are common in the basal region (arrowhead). The superficial cells are PAS-positive. Below this layer kerato-hyaline granules (arrow) are also found in the cytoplasm of the squamous cells. In the vaginal lumen (asterisk) a PAS-positive secretion is seen. 170X.

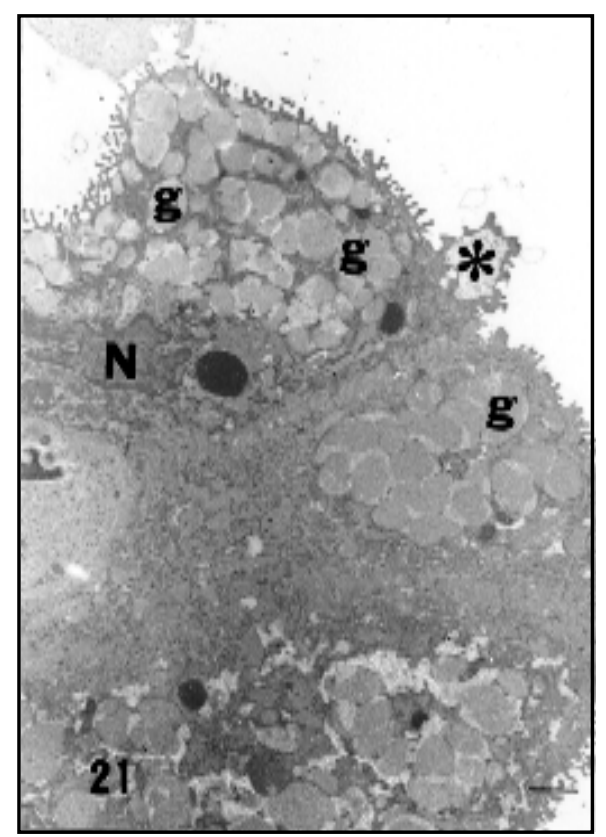

Fig 21 - Electronmicrograph of vaginal epithelium of Calomys callosus during dioestrous 2. Prismatic cells seen in Fig. 20. Observe nucleus (n), many secretory granulea (g) are present in the cytoplasm of these cells. On the apical surface of the cells, certain expansions which may represent the process of granule extrusion (asterisk) are seen. 6000X. Bar $-1 \mu \mathrm{m}$.

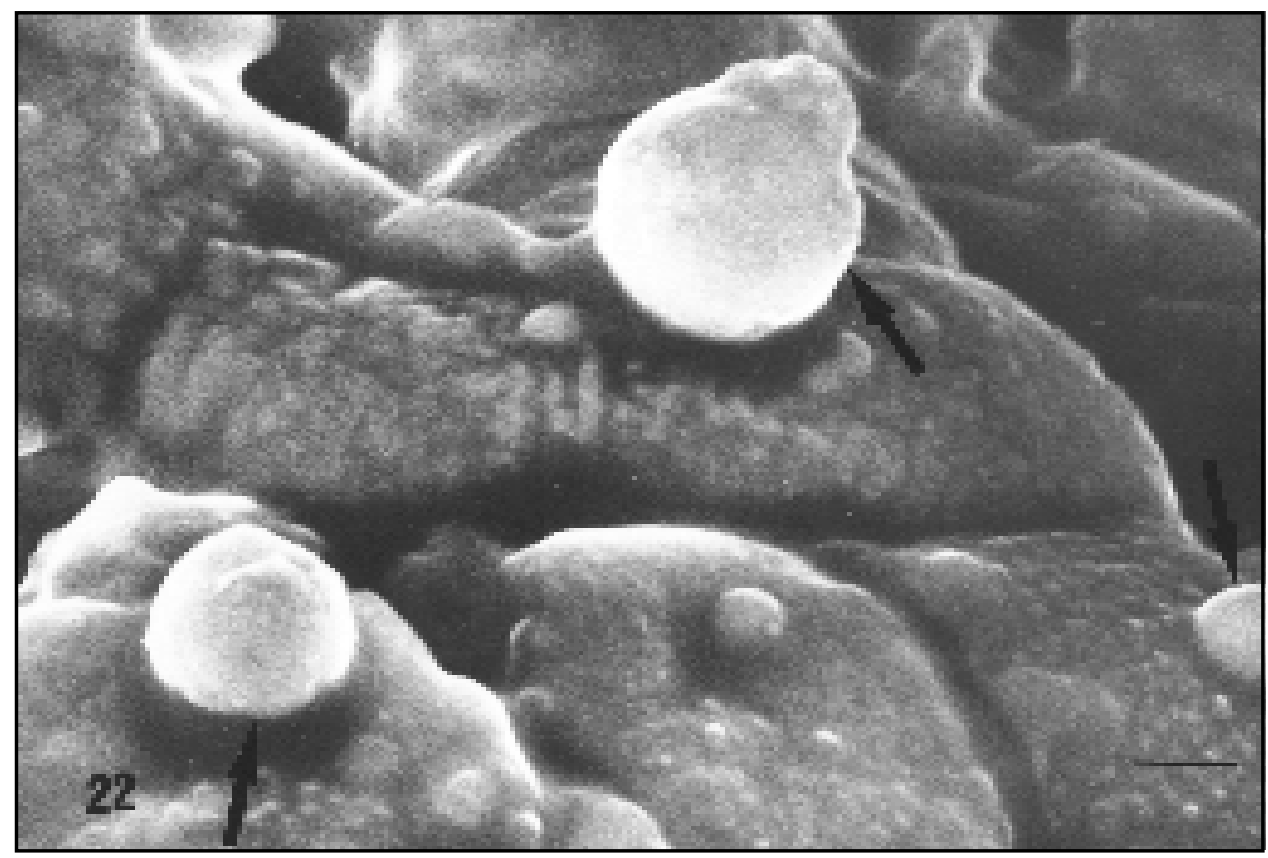

Fig 22 - Scanning electron micrograph from the vaginal epithelium of Calomys callosus in dioestrus 2 . In cell surfaces extrusion of secretion granule (arrow). 11000X. Bar $-1 \mu \mathrm{m}$. 


\section{DISCUSSION}

During the oestrous cycle, the vaginal epithelium of C. callosus undergoes profound morphological changes. This phenomenon also occurs in rat (Parakkal, 1974; Centola, 1978; Vijayasaradhi \& Gupta, 1987) and mouse (Allen, 1927; Young \& Hosking, 1986; Nelson et al, 1991; Horvat et al, 1992). The acquisition of secretory activity, changes in the pattern of keratinization, and an increase in the rate of mitosis were also seen. As in other animals, these changes probably occur due to oscillating levels of ovarian hormones.

In the proestrus phase, the oestrogen level is maximal and influences the keratinocytes which present a greater fluidity of the plasma membrane (Reddy et al.,1989). In addition to this indirect effect, oestrogen directly influences the enzyme glucose-6-phosphatase which has an important role in keratin synthesis (Kang \& West, 1982). Roop (1987) has demonstrated that oestrogen modulates the expression of the DNA segment responsible for keratin synthesis. These data, obtained from studies in rats and mice, suggest that in Calomys callosus, the process of keratinization, which starts in proestrus and becomes maximal in oestrus, is related, either directly or indirectly, to high oestrogen levels.

It is known that copulation occurs during oestrus; thus, greater protection of the vaginal mucous layer is necessary and this is provided by the keratin layer, by the increased thickness of the other epithelial layers and by the microridges at the surface of the cells, wich can hold mucus at the luminal surface of the vagina (Lamb et al., 1978). The increased thickness of epithelial layers is the result of mitosis in a great number of basal cells. A similar fact was observed by Galand $e t$ al. (1971) who demonstrated that in mice, during the oestrogenic phase, there is an increase in the number of mitotic figures due to a reduction of the $\mathrm{S}$ phase of the cellular cycle, thus reducing the duplication time of DNA.

Morphologically, the end of oestrus is marked by the liberation of the keratin to the vaginal lumen and a reduction in epithelial thickness. This moment marks the transition from oestrus to metoestrus 1 . As the cycle proceeds, the apical portion of the vaginal epithelium is characterized by glycogen deposits as noted by ultrastructural evalu- ation and by the PAS reaction, characterizing metoestrus 2. During metoestrus, an intense leukocyte infiltration is observed among the epithelial cells as these migrate towards the vaginal lumen. This leukocyte infiltration is a well known phenomenon and has already been described by various authors (Busch, 1966; Holtz et al., 1968). Thus, by a still unclear mechanism, the leukocytes migrate through the epithelium towards the lumen, assisting in protection from infectious agents (Corbeil et al., 1985), or to accomplish the phagocytosis of spermatozoa residues still present in the vaginal lumen (Branscheid \& Holtz, 1988).

In dioestrus 1 , the epithelium of the superficial layer is cubic and presents ultrastructural and histochemical features characteristic of secretory cells. This secretory activity may be related to increased progesterone levels, since in mice the maximum concentration of progesterone occurs in dioestrus 1 (Walmer et al., 1992). As the cycle continues, the superficial layer cells become prismatic or globous with a great number of secretory granules; this period is characterized as dioestrus 2 .

The secretion produced by the epithelial cells is discharged to the vaginal lumen where, together with the secretions from the cervix, seems to perform an important role in the defense of the epithelium, since the leukocytes remain immersed in this gelatinous net, and thus may exert their phagocytic function (Branscheid \& Holtz, 1988).

In diestrus 2, kerato-hyaline granules associated with intermediate filaments of $10 \mathrm{~nm}$ diameter accumulate below the layer of secretory cells forming the keratin layer present in the subsequent phase: the proestrus phase. In proestrus, secretory cells were observed in the keratinized layer, reflecting an advanced degenerative condition which persisted since the last dioestrus.

In conclusion, the present results suggest that surface cells of vaginal epithelium could be secretory or keratinized, probably in response to ovarian hormones. Additionally, the present study gives evidence of wide cellular variety found in vaginal epithelium of $C$. callosus during oestrous cycle.

Acknowledgements - The authors thank Mr. Hélgio $\mathrm{H}$. Wernech for excellent assistance. Dr. José Roberto Mineo kindly reviewed the manuscript. The authors wish to express their appreciation to Dra. Estela Maris Andrade Forell Bevilacqua for her interest and helpful suggestions during this investigation and Dr. Hélio Chiarini Garcia for his extensive 
instruction in the techniques and principles of scanning electron microscopy.

\section{REFERENCES}

ALLEN, E., 1927, The oestrus cycle in the mouse. American Journal of Anatomy, 30(3): 297-371.

BRANSCHEID, W. \& HOLTZ, W., 1988, Histochemical examination of the vaginal epithelium of sows at varìous stages of the estrus cycle. Anat. Histol. Embriol., 17: 12-26.

BUSCH, W., 1966, Die periodischen veränderungen des vaginal epithels beim schwein und die möglichkeiten ihrer heranziehung zur graviditätsdiagnose. Wiss. Z. Humboldt-Uni v. Berlim, Math. Nat. R., 15: 833-865.

CENTOLA, G. M., 1978, Surface features of exfoliated vaginal epithelial cells during oestrous cycle of the rat examined by scanning electron microscopy. J. Anat., 127: 553-561.

CORBEIL, L. B., CHATTERJEE, A., FORESMAN, L. \& WESTFALL, J. A., 1985, Ultrastruture of cycle change in the murine uterus, cervix and vagina. Tissue \& Cell, 17: 53-68.

FINN, C. A. \& MC LAREN, A. , 1967, A study of the early stage of implantation in mice. J. Reprod. Fertil., 13: 259-267.

GALAND, P., LEROY, F. \& CHRETIEN, J., 1971, Effect of vaginal on proliferation and histological changes in the uterus and vagina of mice. J. Endocr., 49: 243-252.

HOLTZ, W., SMIDT. D., THUME, O. \& WESELOH, W., 1968, Veränderugen des scheiden-pH, der rektal und vaginal gemessenen Körpertemperatur und des scheidenepithels in abhängigkeit vom sexualzyklus beim göttinger zwergschwein. Zbl. Vet. Med, 15: 329-352.

HORVAT, B., VRCIC, H. \& DAMJANOV, I., 1992, Transdiferentiation of murine squamous vaginal epithelium in proestrus is associated with changes in the expression of keratin polypeptides. Experimental Cell Research, 199: 234-239.

JUSTINES, G. \& JOHNSON, K. M., 1969, Imune tolerance in Calomys callosus infected with machupo virus. Nature, 222: 1090-1091.

JUSTINES, G. \& JOHNSON, K. M., 1970, Observations on the laboratory breeding of the cricetidae rodent Calomys callosus. Lab. Anim. Core, 20: 57-60.

KANG, Y. \& WEST, W. L., 1982, Ultrastructural localization of glucose-6-phosphatase and alkaline phosphatase in the vaginal epithelium of rat. Journasl of Morphology, 171: 1-10.

LAMB, J. C., NEWBOLD, R. R., STUMPF, W. E. \& MCLACHLAN, J. A., 1978, Transiotional changes in the surface epithelium of the cycling mouse vagina, cervix and uterus: scanning electron microscopic studies. Biol. reprod., 19: 701-711.

MCMANUS, J. F. A., 1948, Histological and histochemical use of periodic acid. Stain Tecnology, 23(3): 99-108.
MELLO, D. A., 1978. Biology of Calomys callosus under laboratory conditions (Rodentia, Cricetidae). Rev. Bras. Biol., 38(4): 807-811.

MELLO, D. A., 1981, Studies on reproduction and longe vity of Calomys callosus (Renger, 1830) under laboratory conditions ( Rodentia, Cricetidae ). Rev. Bras. Biol., 41(4): 841-843.

NELSON, K. G., TAKAHASHI, T., BOSSERT, N. L., WALMER, D. K. \& MCLACHLAN, J. A.,1991, Epidermal growth factor replaces estrogen in the stimulation of female genital-tract growth and differentiation. Proc. Natl. Acad. Sci., 88: 21-25.

PARAKKAT, P. F., 1974, Cyclical changes in the vaginal epithelium of the sun by scanning electron microscopy. Anat. Rec., 178: 529-538.

PETTER, F., KARIMI, Y. \& ALMEIDA, C. R., 1967, Un nouvean ranger de laboratoire, lé cricetidé (Rodentia, Cricetidae). C. R. Acad. Paris, 265: 1974-1976.

RIBEIRO, R. D., 1973, Novo reservatório do Trypanosoma cruzi. Rev. Bras. Biol., 33: 429.437.

REDDY, A. G., SHIVAJI, S. \& GUPTA, P. D., 1989, Effect of estradiol on the membrane fluidity of the rat vaginal epithelial cells. J. Steroid. Biochem, 33(6): 1229-1233.

ROOP, D. R., 1987, Regulation of keratìn gene expression during differentiation of epidermal and vaginal epithelial cells. Current Topics in Developmental Biology, 22: 195-207.

SHORR, E., 1945, A new technic for staining vaginal smears. A single differentive stain. Science, 84: 545.

VIJAYASARADHI, S. \& GIJPTA, P. D., 1987 Keratinization of rat vaginal epithelium. I - Cell surface study during natural and induced keratinization. J. Submicrosc. Cytol., 19: 595-603.

WALMER, D. K., WRONA, M. A., HLTGHES, C. L. \& NELSON, K. G., 1992, Lactoferrin expression in the mouse reproductive tract during the natural estrous cycle: Correlation with circulating estradiol and progesterone. Endocrinodogy, 131 (3): 458-1466.

YOUNG, W. G. \& HOSKING, A. R., 1986, Langerhans cells in murine vaginal epithelium affected oestrogen and topical vitamin A. Acta. Anat., 125: 59-64. 